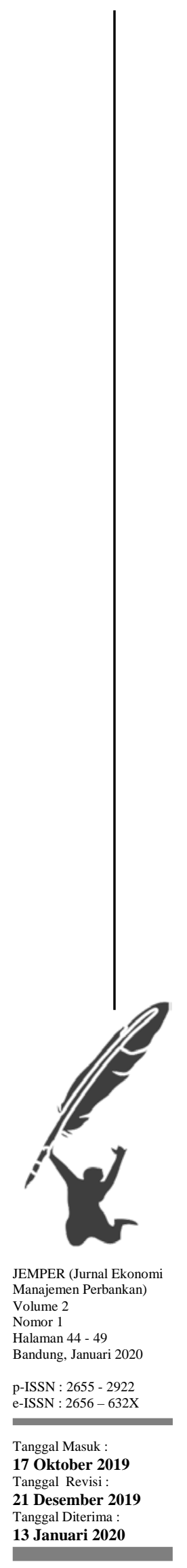

JEMPER(Jurnal Ekonomi Manajemen Perbankan)

http://jurnal.usbypkp.ac.id/index.php/jemper

\title{
ANALISIS PERANAN DIGITAL MARKETING TERHADAP MINAT BERWIRAUSAHA (Survey Tempat Kuliner di Kota Cimahi Kelurahan Cimahi Kecamatan Cimahi Tengah)
}

\author{
Devi Intan Setyaningsih ${ }^{1}$ \\ Universitas Sangga Buana YPKP Bandung \\ deviintans98@gmail.com \\ Hadi Ahmad Sukardi ${ }^{2}$ \\ Universitas Sangga Buana YPKP Bandung \\ dias.mangarai@gmail.com
}

\begin{abstract}
Marketing director of digital case is about the marketing including wonderful indonesia a branding the use of various based media the web as blog, a web site institute, e-mail, adwords, on the great commission nor the social networking.The lack of interest in made by is the wish of , of interest it was, as well as the willingness of work hard or are strong willed of actually trying to meet the needs of his life and create new businesses without fear with the ever present risk that was going to happen as well as will not cease to learn from the failure of a made by.
\end{abstract}

\section{Keywords : Digital Marketing, Entrepreneurial Interest}

\begin{abstract}
Abstrak
Digital marketing adalah kegiatan marketing termasuk branding yang menggunakan berbagai media berbasis web seperti blog, web site, e-mail, adwords, ataupun jejaring sosial. Minat berwirausaha adalah keinginan, ketertarikan, serta kesediaan bekerja keras atau berkemauan keras untuk berusaha memenuhi kebutuhan hidupnya dan menciptakan usaha baru tanpa merasa takut dengan resiko yang akan terjadi serta senantiasa belajar dari kegagalan dalam berwirausaha.
\end{abstract}

Kata Kunci : Pemasaran Digital, Minat Berwirausaha 


\section{PENDAHULUAN}

Perkembangan Internet telah memengaruhi perkembangan ekonomi di Indonesia. Salah satunya adalah dapat melakukan pemasaran melalui digital marketing. Pemasaran dijital atau Digital Marketing merupakan suatu bentuk program mempromosikan atau memasarkan sebuah merk dengan menggunakan media digital (Internet). Digital Marketing saat ini merupakan media yang sangat efektif dan popular untuk dapat dijadikan sebagai media promosi. Hal ini terjadi akibat adanya perkembangan dalam dunia internet dan teknologi yang memiliki dampak cukup tinggi pada angka pengguna internet sehingga internet menjadi sebuah market yang sangat prospektif. Digital Marketing ini juga merupakan solusi yang banyak dipakai pada saat ini karena dapat menjangkau pelanggan secara maksimal.

Indonesia masuk kedalam 10 besar negara dengan pengguna internet terbesar di dunia, tepatnya menduduki peringkat ke-6 di atas Rusia, Jerman, Meksiko dan Nigaria. Pada tahun 2013 sekitar 72,8 juta saja dan kemudian meningkat menjadi 83,7 juta pada tahun 2014. Di tahun 2015 terjadi peningkatan menjadi 93,4 juta yang akhirnya menjadi 102,8 juta di tahun 2016. Pada tahun 2017, mencapai 112,6 juta pengguna dan kembali melonjak pada tahun 2018 mencapai 123 juta.

Penggunaan digital marketing sudah sangat berkembang mengingat pengguna internet di Indonesia yang semakin meningkat. Menurut survey yang dilakukan oleh Asosiasi Pengguna Jasa Internet Indonesia (APJII) menunjukkan bahwa penetrasi dan perilaku pengguna internet di Indonesia tumbuh 10,12\%. Data diambil selama periode Maret hingga 14 April 2019. Dari total populasi sebanyak 264 juta jiwa penduduk Indonesia, ada sebanyak 171,17 juta jiwa atau sekitar $64,8 \%$ yang sudah terhubung ke internet. Situs yang sering digunakan oleh penduduk Indonesia salah satunya adalah Google dan Youtube. Dengan adanya Google dan Youtube tidak heran apabila digital marketing dapat berkembang secara pesat sehingga dapat menimbulkan suatu minat berwirausaha bagi sekelompok orang khusunya di Kota Cimahi.

Minat berwirausaha muncul karena adanya pengetahuan dan informasi mengenai kewirausahaan yang kemudian dilanjutkan untuk berpartisipasi secara langsung dalam rangka mencari pengalaman dan akhirnya timbul keinginan untuk memperhatikan pengalaman yang telah didapatkan tersebut. Serta mempunyai perasaan senang dan mempunyai keinginan untuk terlibat dalam kegiatan pengambilan resiko, untuk menjalankan bisnis atau usaha sendiri dengan memanfaatkan peluang-peluang bisnis yang ada, dan menciptakan bisnis baru dengan pendekatan inovatif. Minat berwirausaha tidak dimiliki dengan begitu saja, melainkan dapat dipupuk dan dikembangkan.

Salah satu contoh dari adanya minat berwirausaha adalah munculnya perusahaan yang bergerak dibidang kuliner. Kuliner bukan lagi produk konsumsi untuk memenuhi kebutuhan biologis manusia semata. Saat ini kuliner sudah menjadi sebuah gaya hidup baru di kalangan masyarakat. Pertumbuhan kuliner sangat berkembang pesat dan semakin diminati oleh masyarakat. Khususnya di Kota Cimahi yang merupakan kota industri saat ini menjadi kota potensial untuk berbisnis dalam segala bidang. Salah satunya bidang kuliner yang saat ini sudah berkembang dengan pesat. Kota Cimahi menjadi salah satu tempat yang memiliki banyak tempat makan seperti restoran atau kafe. Maka saat ini populernya kuliner di Kota Cimahi bermunculan dengan berbagai jenis restoran dan café yang semakin kreatif dan inovatif yang menarik untuk masyarakat kunjungi.

\section{LITERATUR}

Digital marketing atau Pemasaran digital adalah suatu usaha untuk mempromosikan sebuah merek dengan menggunakan media digital yang dapat menjangkau konsumen secara tepat waktu, pribadi, dan relevan. Menurut Ridwan Sanjaya \& Josua Tarigan 
(2009:47) menyatakan bahwa digital marketing adalah kegiatan marketing termasuk branding yang menggunakan berbagai media berbasis web seperti blog, web site, e-mail, adwords, ataupun jejaring sosial. Dan menurut Coviello, Milley And Marcolin (2001:26) menyatakan bahwa digital marketing ialah penggunaan internet dan penggunaan teknologi interaktif lain untuk membuat dan menghubungkan dialog antara perusahaan dan konsumen yang telah teridentifikasi.

Menurut Sutanto dalam Sifa (2016:277) menyatakan bahwa Minat berwirausaha adalah keinginan, ketertarikan, serta kesediaan bekerja keras atau berkemauan keras untuk berusaha memenuhi kebutuhan hidupnya dan menciptakan usaha baru tanpa merasa takut dengan resiko yang akan terjadi serta senantiasa belajar dari kegagalan dalam berwirausaha. Menurut Basrowi (2016:34) menyatakan bahwa Minat berwirausaha adalah perubahan sikap dan pandangan generasi muda calon intelektual bangsa kita dan perubahan sikap orang tua yang menyenangi dan mengizinkan putra-putrinya untuk terjun kebidang bisnis. Para remaja banyak mengatakan bahwa mereka sangat menyenangi kegiatan bisnis, karena pekerjaan bisnis cukup menjanjikan dimasa depan. Untuk mengantisipasi pekerjaan bisnis, mereka mempersiapkan bekal, berupa mental dan keterampilan menunjang.

\section{METODE PENELITIAN}

Metode penelitian yang digunakan adalah penelitian Deskriptif dan Asosiatif. Jenis penelitian ini berdasarkan tujuan nya adalah Basic Research (Penelitian dasar). Jenis penelitian ini berdasarkan metode nya adalah Metode Survey. Populasi dalam penelitian in adalah sebanyak 112 tempat kuliner. Namun dalam penilitian ini peneliti tidak mungkin untuk dapat meneliti seluruh populasi. Dikarenakan beberapa alas an diantaranya keterbatasan waktu penelitian, keterbatasan tenaga dan biaya. Maka peniliti meneliti sebagian objek populasi yang telah ditentukan, dengan catatan bagian yang diteliti tersebut dapat mewakili bagian lain yang diteliti. Maka sampel yang diteliti oleh peneliti didalam penelitian ini sebanyak 25 responden.

Metode analisis data yang digunakan oleh peneliti didalam penelitian ini adalah uji validitas dihitung untuk membandingkan nilai $r_{\text {hitung }}$ (correlated item-total correlation) dengan nilai $r_{\text {tabel }}$ jika $r_{\text {hitung }}>r_{\text {tabel }}$ maka pernyataan tersebut dikatakan sebagai pernyataan yang valid. Uji reliabilitas bertujuan untuk mengukur konsistensi sebuah kuesioner yang digunakan dalam penelitian. Analisis koefisien regresi sederhana adalah analisis statistik yang digunakan untuk memprediksi ada tidaknya keterkaitan antar variabel dalam penelitian. Analisis koefisien korelasi digunakan untuk mengetahui kekuatan hubungan antar variabel independen dengan variabel dependen. Analisis koefisien determinasi adalah alat analisis yang digunakan untuk mengetahui seberapa besar pengaruh dari variabel X (Digital Marketing) terhadap variabel Y (Minat Berwirausaha). Uji hipotesis (uji t) digunakan untuk mengetahui sejauh mana pengaruh variabel X (Digital Marketing) terhadap variabel Y (Minat Berwirausaha).

\section{HASIL DAN PEMBAHASAN}

Tabel 1.1 Hasil Uji Validitas

\begin{tabular}{ccc}
\hline $\begin{array}{c}\text { Variabel X } \\
\text { (Digital }\end{array}$ & $\begin{array}{c}\text { Variabel Y } \\
\text { (Minat }\end{array}$ & Valid \\
Marketing) & Berwirausaha) & \\
\hline Sumber : data primer yang telah diolah peneliti, 2019
\end{tabular}


Hasil uji validitas yang dilakukan pada kedua variabel antara variabel X (Digital Marketing) dan variabel Y (Minat Berwirausaha) dapat diketahui bahwa seluruh indikator yang digunakan untuk mengukur variabel-variabel dalam penelitian memiliki koefisien korelasi yang lebih besar dari nilai $r_{\text {tabel }}$ dengan signifikan 5\% yakni 0,396 sehingga seluruh indicator yang digunakan dalam penelitian ini dinyatakan valid.

Tabel 1.2 Hasill Uji Reliabilitas

\begin{tabular}{ccc}
\hline Variabel & $\begin{array}{c}\text { Nilai Hitung } \\
\text { Cronbach's Alpha }\end{array}$ & Keterangan \\
\hline Digital Marketing & 0,954 & Reliabel \\
Minat Berwirausaha & 0,995 & Reliabel \\
\hline Sumber : data primer yang telah diolah peneliti, 2019
\end{tabular}

Hasil uji reliabilitas dinyatakan reliabel jika nilai Cronbach's Alpha $>0,6$. Dimana dapat diketahui bahwa hasil pengujian menunjukan nilai Cronbach's Alpha kedua variabel dalam penelitian ini bernilai $>0,6$ sehingga kedua variabel tersebut dinyatakan reliabel

Tabel 1.3 Hasil Uji Deskriptif

\begin{tabular}{ccc}
\hline Variabel & Nilai uji deskriptif & Keterangan \\
\hline Digital Marketing & 3,05 & Cukup Baik \\
Minat Berwirausaha & 3,81 & Baik \\
\hline Sumber : data primer yang telah diolah peneliti, 2019
\end{tabular}

Hasil uji deskriptif untuk kedua variabel antara variabel X (Digital Marketing) terhadap variabel Y (Minat Berwirausaha) memiliki hasil uji untuk variabel X (Digital Marketing) memiliki nilai rata-rata sebesar 3,05 yang berada pada interval 2,61 - 3,40 sehingga dapat diimplementasikan dengan cukup baik. Dan untuk variabel Y (Minat Berwirausaha) memiliki nilai rata-rata sebesar 3,81 yang berada pada interval 3,41 - 4,20 sehingga dapat diimplementasikan dengan baik.

Tabel 1.4 Hasil Analisis Koefisien Regresi Sederhana

\begin{tabular}{cccccc}
\hline Model & \multicolumn{2}{c}{$\begin{array}{c}\text { Unstandardized } \\
\text { Coefficients }\end{array}$} & $\begin{array}{c}\text { Standardized } \\
\text { Coefficients }\end{array}$ & t & \multirow{2}{*}{ Sig. } \\
\cline { 2 - 4 } & B & Std Error & Beta & & \\
Digital Marketing & $-40,741$ & 7,881 & & $-5,170$ & .000 \\
& 2,233 & .183 & .928 & 12,191 & .000 \\
\hline
\end{tabular}

Sumber : data primer yang telah diolah peneliti, 2019

Berdasarkan hasil analisis yang tersaji pada Tabel di atas, dapat diketahui bahwa koefisien regresi untuk variabel X yaitu 2,233 dengan konstanta sebesar -40,741. Berdasarkan data tersebut maka dapat disusun persamaan regresi sebagai berikut:

$$
Y=-40,741+2,233(X)
$$

Jika diuraikan secara lebih rinci, maka:

1. Nilai -40,741 merupakan nilai konstanta dalam persamaan ini. Nilai konstanta bermakna bahwa Minat Berwirausaha bernilai -40,741 jika koefisien regresi variabel Digital Marketing bernilai 0 atau ditiadakan.

2. Koefisien regresi Digital Marketing terhadap Minat Berwirausaha bernilai 2,233 artinya jika diasumsikan apabila Digital Marketing meningkat 1 maka Minat Berwirausaha akan meningkat 2,233. Dengan demikian Digital Marketing 
memberikan kontribusi positif sebesar 2,233 dengan asumsi variabel bebas lainnya bersifat konstan,

Tabel 1.5 Hasil Analisis Koefisien Korelasi

\begin{tabular}{ccc}
\hline & Digital Marketing & Minat Berwirausaha \\
\hline Digital Marketing & 1 & $.928^{* *}$ \\
& 26 & .000 \\
Minat Berwirausaha & $.928^{* *}$ & 26 \\
& .000 & 1 \\
& 26 & 26 \\
\hline Sumber : data primer yang telah diolah peneliti, 2019
\end{tabular}

Berdasarkan hasil pengolahan data tersebut maka :

1. Nilai korelasi variabel digital marketing terhadap minat berwirausaha $=0,928$ sehingga kedua variabel tersebut memiliki tingkat hubungan yang sangat kuat.

2. Nilai korelasi variabel minat berwirausaha terhadap digital marketing $=0,928$ sehingga variabel tersebut berada dalam hubungan yang sangat kuat.

Tabel 1.6 Hasil Analisis Koefisien Determinasi

\begin{tabular}{ccccc}
\hline Model & $\mathbf{R}$ & R Square & $\begin{array}{c}\text { Adjusted } \\
\text { R Square }\end{array}$ & $\begin{array}{c}\text { Std Error } \\
\text { of Estimate }\end{array}$ \\
\hline $\mathbf{1}$ & $.928^{* *}$ & .861 & .855 & 18,61468 \\
\hline
\end{tabular}

Sumber : data primer yang telah diolah peneliti, 2019

Dimana :

$$
\mathrm{KD}=\boldsymbol{r}^{2}
$$

$\mathrm{KD}$ = seberapa jauh perubahan variabel $\mathrm{Y}$ yang dipengaruhi oleh variabel $\mathrm{X}$

Berdasarkan pengolahan data yang telah disajikan dalam tabel di atas maka,

$$
\begin{aligned}
& \mathrm{KD}=0, \mathbf{9 2 8}^{2} \\
& =0,861
\end{aligned}
$$

Berdasarkan tabel diatas diketahui bahwa hasil pengolahan data menunjukkan nilai koefisien determinasi sebesar 86,1\%. Hasil perhitungan tersebut bermakna bahwa digital marketing mempengaruhi minat berwirausaha sebesar 86,1\% sedangkan sisanya sebanyak 13,9\% minat berwirausaha dipengaruhi oleh faktor lain yang tidak diteliti dalam penelitian ini.

Tabel 1.7 hasil Uji Hipotesis (Uji t)

\begin{tabular}{cccccc}
\hline Model & \multicolumn{2}{c}{$\begin{array}{c}\text { Unstandardized } \\
\text { Coefficients }\end{array}$} & $\begin{array}{c}\text { Standardized } \\
\text { Coefficients }\end{array}$ & t & Sig. \\
\cline { 2 - 4 } Digital Marketing & $\mathrm{B}$ & Std Error & Beta & & \\
& $-40,741$ & 7,881 & & $-5,170$ & .000 \\
& 2,233 & .183 & .928 & 12,191 & .000 \\
\hline
\end{tabular}

Sumber : data primer yang telah diolah peneliti, 2019

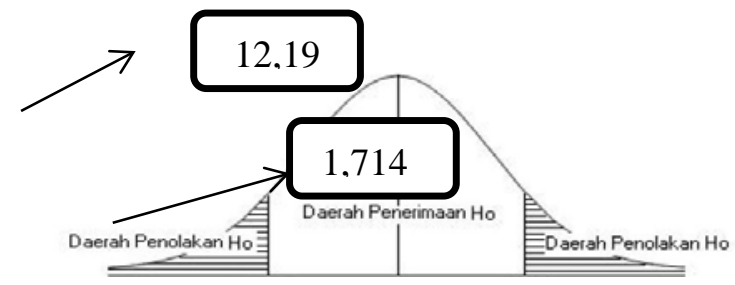

Gambar.1 Hasil Uji Hipotesis Secara Parsial (Uji t) 
Berdasarkan hasil pengolahan data pada tabel diatas, maka dapat dijelaskan hal-hal sebagai berikut :

Nilai thitung sebesar 12,191 dengan taraf signifikansi $\alpha$ sebesar 5\%, maka nilai $t_{\text {tabel }}$ atau $\mathrm{t}_{0,05.85}=1,714$. hasil perhitungan menunjukkan tingkat signifikansi sebesar $0.000<0.05$ maka Ho ditolak atau dengan kata lain digital marketing (X) berpengaruh signifikan terhadap minat berwirausaha $(\mathrm{Y})$.

\section{SIMPULAN}

Hasil uji validitas dalam penelitian ini dapat diketahui bahwa seluruh indikator yang digunakan dalam penelitian ini dinyatakan valid karena memiliki koefisien korelasi lebih besar dari nilai $r_{\text {yabel }}$. Hasil uji reliabilitas kedua variabel di dalam penelitian ini bernilai > 0,6 sehingga kedua variabel tersebut dinyatakan reliabel. Hasil uji deskriptif untuk kedua variabel memiliki hasil uji untuk variabel X (Digital Marketing) memiliki nilai rata-rata sebesar 3,05 yang berada pada interval 2,61 - 3,40 sehingga dapat diimplementasikan dengan cukup baik. Dan untuk variabel Y (Minat Berwirausaha) memiliki nilai rata-rata sebesar 3,81 yang berada pada interval 3,41-4,20 sehingga dapat diimplementasikan dengan baik. Hasil uji analisis koefisien regresi sederhana jika nilai konstanta dalam penelitian ini bernilai -40,741. Hal ini menunjukkan bahwa digital marketing rendah atau dalam artian minat berwirausaha di Kota Cimahi Kelurahan Cimahi Kecamatan Cimahi Tengah kurang. Dan hasil analisis regresi terdapat nilai slop sebesar 2,233. Hal ini bermakna jika diasumsikan variabel digital marketing mengalami peningkatan sebesar 1 maka ketidakminatan akan berwirausaha akan berkurang sebesar 2,233. Hasil analisis koefisien korelasi antara Digital Marketing dan Minat Berwirausaha pada Tempat Kuliner di Kota Cimahi Kelurahan Cimahi Kecamatan Cimahi Tengah berniai 0,928. Dengan kata lain variabel digital marketing dan minat berwirausaha memiliki kategori hubungan yang kuat. Hal ini dapat dilihat dari hasil analisis koefisien bernilai 0,928. Hasil uji analisis koefisien determinasi menunjukkan nilai koefisien determinasi sebesar 86,1\%. Hasil perhitungan tersebut bermakna bahwa digital marketing mempengaruhi minat berwirausaha sebesar 86,1\% sedangkan sisanya sebanyak 13,9\% minat berwirausaha dipengaruhi oleh faktor lain yang tidak diteliti dalam penelitian ini. Hasil uji hipotesis (uji t) menunjukan dengan nilai thitung sebesar 12,191 dengan taraf signifikansi $\alpha$ sebesar $5 \%$, maka nilai $t_{\text {tabel }}$ atau $t_{0,05.85}=1$,714. Hasil perhitungan menunjukkan tingkat signifikansi sebesar $0.000<0.05$ maka Ho ditolak atau dengan kata lain digital marketing $(\mathrm{X})$ berpengaruh signifikan terhadap minat berwirausaha $(\mathrm{Y})$.

\section{DAFTAR PUSTAKA}

Alma, Buchari. 2013. Kewirausahaan. Bandung: Alfabeta

Kasmir. 2010. Kewirausahaan. Jakarta: PT Rajagrafindo Persada

Nitisusastro M. 2012. Kewirausahaan dan Manajemen Usaha Kecil. Bandung: Alfabeta

Putra BA , Irawan A. 2007. Kewirausahaan UKM Pemikiran dan Pengalaman. Yogyakarta: Graha Ilmu

Sheperd DA, Peters MP, Hisrich RD. 2008. Entrepreneurship Kewirausahaan. Jakarta: Salemba Empat

Tambunan T. 2009. UMKM Di Indonesia. Jakarta: Perpustakaan Nasional KDT 